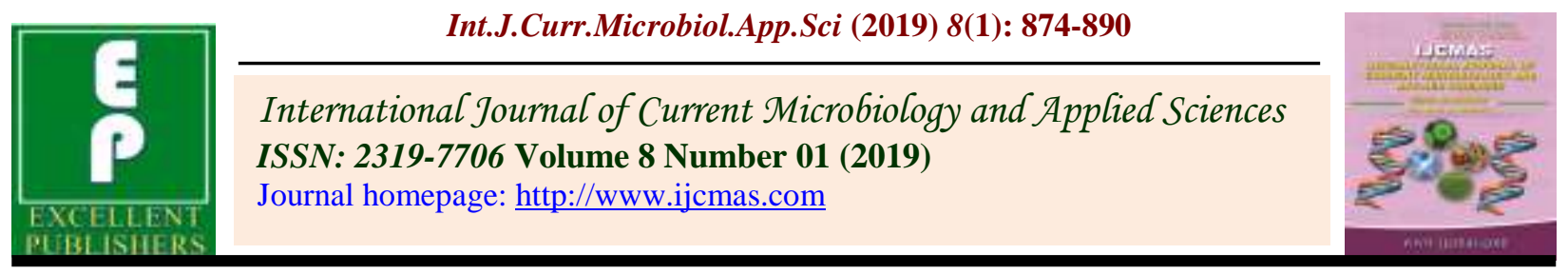

\title{
Biochemical Changes of Mycorrhiza Inoculated and Uninoculated Soils under Differential $\mathrm{Zn}$ and $\mathbf{P}$ Fertilization
}

\author{
Chandrasekaran Bharathi ${ }^{1}$, Natarajan Balakrishnan ${ }^{2 *}$ and Kizhaeral S. Subramanian ${ }^{2}$ \\ ${ }^{1}$ Department of Soil Science and Agricultural Chemistry, ${ }^{2}$ Department of Nano Science and \\ Technology, Tamil Nadu Agricultural University, Coimbatore 641 003, India \\ *Corresponding author
}

Keywords

Arbuscular mycorrhizae, Soil enzymes, Nutrient status Biomass carbon, Glomalin

Article Info

Accepted:

07 December 2018

Available Online:

10 January 2019

\section{A B S T R A C T}

Greenhouse experiment was conducted to assess the soil biochemical change patterns in soils of arbuscular mycorrhizal fungus (AMF)-inoculated and uninoculated maize plants fertilized with varying levels of $\mathrm{P}$ and $\mathrm{Zn}$. Soil samples were collected for mycorrhizal spores, microbial communities, available micronutrients and phosphorus (P) contents besides organic and biomass carbon (BMC), soil enzymes and glomalin. Major portion of $\mathrm{Fe}$ and $\mathrm{Zn}$ fractionations was found to occur in the residual form. AM symbiosis significantly modulated the microbial communities in the soil regardless of low or high $\mathrm{P}$ concentration. The results showed that mycorrhizae had pronounced influence on increasing bacterial population, while less effect was found in the case of fungi and actinomycetes activity in the soil. The positive interaction between $\mathrm{P}$ and $\mathrm{Zn}$ in mycorrhizae treated soil resulted in enhanced growth especially root and nutrient uptake. Soil enzymes, viz. dehydrogenase and acid phosphatase activities in M+ soils, were significantly higher than $\mathrm{M}-$ soil consistently. Overall, the data suggest that mycorrhizal symbiosis enhanced the availability of $\mathrm{P}$ and $\mathrm{Zn}$ as a result of preferential nutrient uptake and biochemical changes that may alleviate micronutrient deficiencies in soil.

\section{Introduction}

Indian agricultural soils are $60 \%$ zinc deficient causing reduction in crop productivity to the tune of 30-40\% (Singh et al., 2005). Zinc use efficiency by crops is hardly exceeds $1 \%$ as the major portion gets fixed in the soil. In addition, soils of arid and semiarid regions of India are very low in organic status as a result of faster decomposition of organic matter that aggravates deficiency of $\mathrm{Zn}$ in soils and mobility of phosphorus in the soil is very low because of its strong adsorption towards clay mineral $\mathrm{Fe}$ and $\mathrm{Al}$ oxides. Arbuscular mycorrhizal fungi (AMF) are obligate endosymbionts, colonize with more than $80 \%$ of terrestrial plant species (Allen, 1991) and live on carbohydrates obtained from root cells. They are key components of the soil biota and account for about $5-50 \%$ of agricultural soils microbial biomass (Olsson et al., 1999) which facilitates in sustaining the fertility status through favorable biochemical changes. Soil 
microbial biomass, the living part of soil organic matter characterizes the microbiological status and quality of the soil. AMF hyphae as they are the main components of soil biomass (Hamel et al., 1991) distribute $\mathrm{C}$ compounds and energy in soil. Since AMF are closely associated with plant roots, most of the biomass retained within top $0-20 \mathrm{~cm}$ of the soil. AMF fungal inoculation increases soil biomass carbon content (Alguacil, 2005) with time (Kim et al., 1998) as a result of increased biomass production. The $\mathrm{C}$ allocated to $\mathrm{AM}$ and thus their contribution to soil $\mathrm{C}$ is of particular importance in tropics because of the low nutrient levels in highly weathered tropical soils).

The increased biomass carbon due to AM symbiosis, promotes soil microbial population and their activities (Tarafdar and Marschner, 1994) by altering root exudation of carbohydrates (Wamberg et al., 2003) and are expected to influence rhizosphere population as well (Hayman, 1983). In turn, biologically active substances such as amino acids and hormones produced by soil microorganism stimulate the growth of AMF. The carbonaceous product produced by AM fungal hyphae in soil is glomalin, a recalcitrant glycoprotein containing $30-40 \%$ C. It may comprise as much as $2 \%$ of soil by weight which makes a large contribution to active soil organic C pools (Rillig et al., 2003). Concentration of glomalin ranges from 2-15 $\mathrm{mg} \mathrm{g}^{-1}$ of soil in temperate climate and 3.94 $\mathrm{mg} \mathrm{cm}$ in tropical rain forest accounting for approximately $3.2 \%$ of total soil $\mathrm{C}$ in the $0-10$ $\mathrm{cm}$ soil layer (Lovelock et al., 2004). Pools of organic carbon such as glomalin produced by AMF may even exceed soil microbial biomass by a factor of 10-20 (Rillig et al., 2001). Mycorrhizal symbiosis enhances soil enzymatic activities viz., acid phosphatase and dehydrogenase, which favours the availability of $\mathrm{P}$ and $\mathrm{Zn}$. Acid phospahtase aids in increased uptake of $\mathrm{P}$ from the soil (Leadir $e t$ al., 1998) by the mechanisms such as hydrolysis of soil organic $\mathrm{P}$ (Tarafdar and Claassen, 1988) after the hydrolysis of C-O-P bond by phosphatase enzyme (Tarafdar, 2008) and more utilization of $\mathrm{P}$ in primary metabolism. Moreover, the phosphtase activity was higher in mycorrhizal treated plants particularly with the supply of organic P (Tarafdar and Marchner, 1994). Dehydrogenase enzyme activity serves as a marker of microbiological redox system by measuring microbial oxidative activities in soil (Garcia et al., 1997) and its activity was more in rhizosphere than non rhizosphere soil. It is evident that $\mathrm{Zn}$ is important for the activation of several enzymes. However, dehydrogenase activity was decreased by $95 \%$ due to $\mathrm{Zn}$ addition in metal contaminated soil (Kelly and Tate 1998). Recently Subramanian et al., (2008) reported that mycorrhizal symbiosis improved both the availability of $\mathrm{P}$ and $\mathrm{Zn}$ as a consequence of synergistic interaction between these two nutrients.

We hypothesized that mycorrhizal symbiosis orchestrates biochemical changes such as biomass carbon, glomalin concentration and soil enzyme activities that collectively contribute for the improved availability of $\mathrm{Zn}$ in deficient soils. Further the response to mycorrhizal inoculation may vary with the degree of $\mathrm{P}$ fertilization. The synergistic interaction between $\mathrm{Zn}$ and $\mathrm{P}$ may also assist in increased availability of $\mathrm{Zn}$ in soils.

\section{Materials and Methods}

\section{Experimental soil characteristics}

A greenhouse experiment was conducted on a red sandy loam soil belonging to Alfisol (Typic Haplustalf). The experimental soil was neutral in $\mathrm{pH}$ (7.25), free from salinity (EC $0.14 \mathrm{dSm}^{-1}$ ) and extremely low in organic carbon status (0.22\%). Regarding macronutrients, soil had low available N (102 
$\left.\mathrm{mg} \mathrm{kg}{ }^{-1}\right)$ and $\mathrm{P}\left(2.60 \mathrm{mg} \mathrm{kg}{ }^{-1}\right)$ and high in available $\mathrm{K}$ (199 $\left.\mathrm{mg} \mathrm{kg}^{-1}\right)$. The DTPA extractable (available) $\mathrm{Zn}$ was $0.6 \mathrm{ppm}$, which is considered as severely $\mathrm{Zn}$ deficient soil. The experimental soil had indigenous viable AMF spore population $\left(<10\right.$ spores $100 \mathrm{~g}^{-1}$ soil) and the soil was sterilized at $121^{\circ} \mathrm{C}$, and pressure $15 \mathrm{lbs}$ for 20 minutes three times in order to eliminate the interference of native mycorrhizal fungi.

\section{Greenhouse experiment}

The greenhouse experiment was maintained at $24-28^{\circ} \mathrm{C}$, light intensity (800 $-1000 \mu$ mols provided by natural light), relative humidity (60-65\%) and 12-h photoperiod. The treatments consisted of two levels of $\mathrm{P}$ (15 and $\left.30 \mathrm{mg} \mathrm{kg}^{-1}\right)$ and three levels of $\mathrm{Zn}(0,1.25$ and $\left.2.5 \mathrm{mg} \mathrm{kg}^{-1}\right)$ in the presence or absence of AM inoculation. There were 12 treatments each was replicated seven times in a factorial randomized block design (FRBD). Three replications were kept for sampling at 55 days after sowing (DAS) and the remaining four replications at 75 DAS. In a $10 \mathrm{~kg}$ capacity pot, $10 \mathrm{~kg}$ soil was filled and over laid with AM inoculum carrying Rhizoglomus intraradices @10 g pot ${ }^{-1}$ as a thin layer. AM was inoculated $5 \mathrm{~cm}$ below the seeds prior to sowing (applied uniformly as a thin layer). Vermiculite based Am fungal inoculum (Glomus intraradices TNAU-03-06) used in this study was provided by the Department of Microbiology of this university. This strain was cultured in maize plants and propagules comprised of infected root bits and spores were blended in sterile vermiculite. For nonmycorrhizal treatments inoculum without mycorrhizal spres was applied. Pregerminated maize hybrid seeds (COHM-5) were sown on the thin layer of AM inoculum overlaid on $1 \mathrm{~kg}$ of soil. Germination percentage was nearly $95 \%$ on the seventh day of sowing and the seedlings were thinned leaving one plant per pot throughout the experiment. Half the dose of $\mathrm{N}$ and full dose of $\mathrm{K}$ were applied in the form of urea and muriate of potash, respectively, as basal at the time of sowing. Full basal dose of $\mathrm{P}$ was applied as per treatment in the form of single superphosphate. In addition to the macronutrients, three levels of $\mathrm{Zn}$ as $\mathrm{ZnSO}_{4}$ was applied as per treatment. Soil samples collected at 55 and 75 DAS were used for the analysis of enzyme activities, organic carbon, biomass carbon, glomalin, Olsen's P, DTPA extractable $\mathrm{Zn}$ and microbial population.

\section{Soil assay}

\section{Enumeration of mycorrhizal spores in soil}

The indigenous mycorrhizal population in an experimental soil was determined using wet sieving and decantation technique. $100 \mathrm{~g}$ of soil sample was stirred for 1 hour with 1 litre water and the supernatant solution was passed through 45, 106 and $180 \mu \mathrm{m}$ sieves staked one over the other. The washings collected in each sieve was transferred into grid line petriplates and observed under stereo zoom microscope for viable spores at 10X (Gardmann and Nicolson, 1963).

\section{Enumeration of microbial communities in rhizosphere soil}

One gram of soil added to $100 \mathrm{ml}$ of distilled water and $1 \mathrm{ml}$ of the suspension was used for serial dilution up to $10^{-7}$. The dilutions of $10^{-6}$, $10^{-4}$ and $10^{-2}$ were used for bacteria, fungi and actinomycetes, respectively. Transferred $1 \mathrm{ml}$ of appropriate dilution to petridishes and mixed with $15 \mathrm{ml}$ of melted and cooled media (luck worm condition) shaked clockwise and anticlockwise direction and allowed for complete solidification and incubated for 2-7 days in inverted position. The media used for bacteria was nutrient agar medium, fungi were rose bengal agar medium and for actinomycetes was Kenknights agar medium. 
Bacterial colonies were observed after 2 days, for fungi 5-7 days and for actinomycetes 7 days (Allen, 1953).

\section{Soil biochemical analyses}

\section{Biomass carbon}

Soil microbial biomass carbon was determined through chloroform fumigation and $\mathrm{K}_{2} \mathrm{SO}_{4}$ extraction (conversion coefficient $\mathrm{K}$ is 0.45 ). Culturing in closed containers and alkali absorption were employed to obtain soil basal respiration (Jenkinson and Poulson, 1976).

\section{Organic carbon}

Accurately $0.5 \mathrm{~g}$ of soil was weighed and passed through $0.2 \mathrm{~mm}$ sieve added $10 \mathrm{ml}$ of $1 \mathrm{~N} \mathrm{~K}_{2} \mathrm{Cr}_{2} \mathrm{O}_{7}$ and $10 \mathrm{ml}$ of concentrated $\mathrm{H}_{2} \mathrm{SO}_{4}$ allowed for digestion for 30 minutes.

After the expiry of time, $10 \mathrm{ml}$ ortho phosphoric acid, $200 \mathrm{ml}$ distilled water were added and titrated against $0.5 \mathrm{~N}$ ferrous ammonium sulphate using diphenylamine indicator. Blank was run without soil sample and from the amount of $\mathrm{K}_{2} \mathrm{Cr}_{2} \mathrm{O}_{7}$ used for oxidizing organic matter, the organic carbon content in soil was calculated (Walkley and Black, 1934).

\section{Glomalin}

The easily extractable glomalin (EEG) fraction was extracted with $20 \mathrm{mM}$ citrate, $\mathrm{pH}$ 7.0 at $121^{\circ} \mathrm{C}$ for $30 \mathrm{~min}$ (Wright and Updahyaya, 1998). The supernatant was removed by centrifugation at $5000 \mathrm{rpm}$ for 20 min. Extraction was continued till the supernatant was devoid of red brown colour. The supernatant was taken in the test tube and $5 \mathrm{ml}$ of alkaline copper tartarate and $0.5 \mathrm{ml}$ of folin reagent were added. Thirty minutes after colour development, OD was measured at 660 $\mathrm{nm}$ using spectrophotometer.

\section{Dehydrogenase}

Twenty grams of moistened inoculated or uninoculated soil samples were added with 0.2 $\mathrm{g} \mathrm{CaCO}_{3}$ and $2 \mathrm{ml}$ of $1 \%$ triphenyl tetrazoilum chloride and incubated for 24 hours at $30^{\circ} \mathrm{C}$. At the end of incubation period, soil samples were extracted with $25 \mathrm{ml}$ methanol. The microbial activity produces $\mathrm{H}^{+}$ions, which reduces triphenyl tetrazolissum chloride into triphenyl tetrazoilum formazan, which is red in colour. Dehydrogenase activity, the index of microbial activity was determined by measuring the intensity of red colour at 485 nm (Tate and Terry, 1980).

\section{Acid phosphatase}

One-gram soil was mixed with $10 \mathrm{ml} 0.2 \mathrm{M}$ sodium acetate buffer and $0.2 \mathrm{ml} 10 \mathrm{mM} \rho$ nitrophenol phosphate and kept in water bath for 30 minutes. The reaction was terminated by the addition of $2 \mathrm{ml} 200 \mathrm{mM} \mathrm{Na} \mathrm{CO}_{3}$. The mixture was mixed thoroughly, filtered and determined acid phosphatase activity as $\mu$ moles $\rho$-nitrophenol produced per gram per minute at $37^{\circ} \mathrm{C}$ using spectrophotometer at $420 \mathrm{~nm}$ (Tabatabai, 1982).

\section{Soil nutrient analyses}

\section{Olsen's phosphorus}

Five grams of soil sample was mixed with 50 $\mathrm{ml} 0.5 \mathrm{M} \mathrm{NaHCO}$ (pH 8.5) and pinch of Darco $G$ 60. The mixture was shacked in mechanical shaker for 30 minutes and filtered through Whatman No. 40 filter paper. Five ml of the filtrate was pipette out into a $25 \mathrm{ml}$ volumetric flask, added with $4 \mathrm{ml}$ of reagent (1.056 $\mathrm{g}$ ascorbic acid in $200 \mathrm{ml}$ of reagent containing ammonium molybdate, antimony potassium tartarate and sulphuric acid) and made up to $25 \mathrm{ml}$. The intensity of blue color developed was measured at $660 \mathrm{~nm}$ using spectrophotometer. 


\section{DTPA extractable micronutrients}

Ten grams of soil sample was shaken with 20 ml DTPA extractant $(13.1 \mathrm{ml}$ triethanolamine, $1.967 \mathrm{~g}$ (Diethylene Triamine Penta Acetic acid) DTPA and $1.47 \mathrm{~g} \mathrm{CaCl}_{2}$ mixed together, made up to 1 litre and $\mathrm{pH}$ adjusted to 7.3) for $2 \mathrm{hrs}$ and filtered through Whatman No. 42 filter paper and fed into Atomic Absorption Spectrophotometer (Varian Spectra AA 220), Australia.

\section{Statistical analysis}

A two-way analysis of variance (ANOVA) was done for all data and comparisons among means were made using LSD (least square difference) test, calculated at $p \leq$ 0.05.Statistical procedures were carried out with the software package IRRI stat (IRRI, Manila, Philippines).

\section{Results and Discussion}

\section{Microbial population}

Soil treated with AM fungus had significantly higher number of bacteria, fungi and actinomycetes populations than uninoculated control at 75 DAS (Table 1). In contrast application of $\mathrm{P}$ and $\mathrm{Zn}$ had no such influence on bacteria and actinomycetes population while the significant response was observed in the case of fungal population.

\section{Biochemical properties}

\section{Soil enzymes}

Acid phosphatase and dehydrogenase activities of soil inoculated with AM fungus increased significantly $(P \leq 0.01)$ at 55 and 75 DAS in comparison to respective uninoculated soil (Table 2). However the magnitude of increase in acid phosphatase and dehydrogenase activities in rhizosphere soil were found to be observed more at 75 DAS rather than 55DAS. The activity of acid phosphatase was increased with $\mathrm{P}$ levels in both the inoculated and uninoculated mycorrhizal soil at 55 and 75 DAS, regardless of zinc levels. Incremental levels of zinc linearly increased the dehydrogenase activity in both the stages of M+ and M- soil. Such reaction was not seen in the activity of soil acid phosphatase except at the stage of 75 DAS.

\section{Biomass carbon}

Biomass carbon of content of inoculated $(\mathrm{M}+)$ soil was significantly $(P \leq 0.05)$ higher than uninoculated (M-) soil regardless of $\mathrm{P}$ and $\mathrm{Zn}$ levels with the percent increase of $32 \%$ and $15 \%$ respectively (Table 3 ). The biomass carbon content in the AM treated soil increased significantly $(P \leq 0.01)$ in correspondence with increasing levels of $\mathrm{P}$ at 55 DAS. However the magnitude of increase was more at 55 than 75 DAS. Application of incremental levels of zinc progressively increased the biomass carbon content under inoculated condition at 55 DAS over 75 DAS.

\section{Glomalin}

The soil treated with AM fungus had a considerable role on increasing the concentration of glomalin (Table 3). The inoculated soil had significantly $(P \leq 0.01)$ higher glomalin content by $30 \%$ and $25 \%$ at 55 and 75 DAS respectively, over uninoculated soil. The addition of $\mathrm{P}$ in both the inoculated and uninoculated soil significantly increased the glomalin content irrespective of stages. At 75 DAS, graded levels of zinc addition progressively increased $(P \leq 0.01)$ the glomalin content in both AM fungus treated and untreated soil. Whereas the glomalin content was not significantly influenced by $\mathrm{Zn}$ addition at 55DAS. 


\section{Soil fertility status}

\section{Organic carbon}

Organic carbon content in mycorrhizal soil was significantly $(P \leq 0.01)$ higher than untreated soil at 55 and 75 DAS regardless of $\mathrm{P}$ and $\mathrm{Zn}$ levels (Table 4). The increases in organic carbon content of both inoculated and uninoculated soils at two P levels were $14 \%$ and $12 \%$ at 55 DAS and $16 \%$ and $11 \%$ at 75 DAS, respectively. The graded levels of $\mathrm{Zn}$ had no effect on organic carbon content in both stages.

\section{Available $\mathbf{P}$ and $\mathbf{Z n}$}

Soil treated with Glomus intraradices had higher available $\mathrm{P}$ and $\mathrm{Zn}$ than uninoculated soil regardless of varying levels of $\mathrm{P}$ or $\mathrm{Zn}$ application (Table 4 and 5). The treatment with AM fungus was very effective for increasing the concentration of available $\mathrm{P}$ and Zn significantly $(P \leq 0.01)$ in the rhizosphere soil of Zea mays by about $22 \%$ and $26 \%$ at the time of 55 DAS and $30 \%$ and $42 \%$ at 75 DAS respectively, when compared to nonmycorrhizal plants. Increasing levels of $\mathrm{Zn}$ gradually increased the available $\mathrm{P}$ status of both inoculated and uninoculated soils however the values were consistently higher for inoculated soils. The available (DTPAextractable) $\mathrm{Zn}$ increased significantly $(\mathrm{P} \leq$ 0.01) with mycorrhizal inoculation under varying levels of $\mathrm{P}$ or $\mathrm{Zn}$. The percent increase in DTPA- Zn at 55 DAS was 41 and $25 \%$ by P15 and P30, respectively. Conversely, P30 had higher percentage of increase at 75 DAS. Similarly uninoculated soil had higher $\mathrm{Zn}$ in P15 than P30 at 75 DAS

\section{Available micronutrients}

In both stages mycorrhizal inoculation increased the DTPA- $\mathrm{Fe}, \mathrm{Mn}$ and $\mathrm{Cu}$ concentration in soil above the critical limit fixed for experimental soil (Table 5 and 6) over uninoculated control regardless of $\mathrm{P}$ and $\mathrm{Zn}$ levels. However the difference between inoculated and uninoculated soil was more at 55DAS. Similarly application of $P$ had positive impact on increasing the DTPA- Mn and $\mathrm{Cu}$ while $\mathrm{Fe}$ content found to be decreased. The incremental levels of $\mathrm{Zn}$ addition showed gradual increase in DTPA$\mathrm{Fe}, \mathrm{Mn}$ and $\mathrm{Cu}$ content in 55and 75 DAS

The zinc availability in the soil is highly restricted due to fixation of major portion of available form of $\mathrm{Zn}$ caused by chemical reactions. Mycorrhizal symbiosis appears to facilitate release of $\mathrm{Zn}$ from unavailable forms which in turn tend to enhance the availability of $\mathrm{Zn}$. In this study, arbuscular mycorrhizal (AM) fungus inoculation in maize improved organic status, dehydrogenase and phosphatase activities of soils that collectively contributed for the availability of $\mathrm{P}$ and $\mathrm{Zn}$ and may assist in alleviating $\mathrm{Zn}$ deficiency in crop plants.

AM symbiosis significantly modulated the microbial communities in the soil regardless of low or high $\mathrm{P}$ concentration. The results showed that mycorrhizae had pronounced influence on increasing bacterial population, while less effect was found in the case of fungi and actinomycetes activity in the soil. This can be explained by altering root exudation through the changes made in root physiology. Numerous studies have shown conclusively that AM is having synergistic interaction with other beneficial soil microorganism such as $\mathrm{N}$ fixers and $\mathrm{P}$ solubilizers (Caravaca et al., 2003) while AM fungi decrease the activity of some of the microorganism (Ames et al., 1984). AM fungi are the key component of soil micro biota and obviously interacted with other microorganism in the rhizosphere. The interactive effect of AM fungi and phosphate solubilizing bacteria were evaluated by Toro et al., (1997) reported 
that AM fungi increased the size of the phosphate solubilizing bacteria population while bacteria behaved as mycorrhiza helper. The effect of AM fungi on wider soil biota including nematode, fungal biomass as indicated by ergosterol, microbial biomass carbon, phospholipid fatty acid profiles were less pronounced (Cavagnaro et al., 2006).

Analysis of the activity of soil enzymes provides information on biochemical processes proceeding in the soil. Mycorrhizal inoculation increased acid phosphatase activity in all the experimental treatments. Acid phosphates in the rhizosphere play an important role for acquisition of $\mathrm{P}$ by roots (Kabir et al., 1998) and through the hydrolysis of organic P (Tarafdar and Claassen 1988; Helal and Saverbeck, 1991). Acid phosphatase released due to a direct fungal secretion or an induced secretion by plant roots as pointed by Joner et al., (2000); Tarafdar and Marschner, (1994) and its activity was higher in the close vicinity $(0.2-0.8 \mathrm{~mm})$ of maize roots (Kandeler et al., 2002); 2.0-3.1 mm in cumbu (Tarafdar, 2008).

Dehydrogenase activity of AM fungus inoculated soil was consistently higher under varying levels of $\mathrm{P}$ and $\mathrm{Zn}$ and it is considered as a measure of soil microbial activity (Garcia et al., 1997). Therefore due to the central role that soil microorganisms play in the degradation of organic matter and the cycling of nutrient in soil ecosystems, a decrease in dehydrogenase activity could have a significant effect on soil ecosystem. The similar result of increased dehydrogenase activity due to the addition of AM fungi was also reported by Caravaca et al., (2003) in Rhamnus lyciodes seedling. In the present study addition of $\mathrm{P}$ and $\mathrm{Zn}$ also enhanced dehydrogenase activity, which indicates the importance of these nutrients on enzyme activity. However Kelly et al., (1999) reported a reduction of dehydrogenase activity due to the addition of $\mathrm{Zn}$ above the toxic level.
Soil biomass carbon is the active component of soil organic matter. The changes of microbial biomass carbon reflect the process of microorganism propagation and degradation utilizing soil carbon. In this study, mycorrhizal inoculation in soil had intensive microbial population besides higher dehydrogenase activities. On decomposition of microbial tissues, the residues serve as source of carbon for heterotrophic microorganism, which may have contributed for the accumulation of biomass carbon. This was supported by Caravaca et al., (2003) who reported that biomass carbon content of rhizosphere soil was increased by $240 \%$ with respect to control. Over short period changes in microbial biomass carbon can be a sensitive index of changes in the organic matter content of soil.

Glomalin, a iron containing glycoprotein produce by AM fungi as a component of hyphal and spore wall (Rillig et al., 2001) considered as a major sequester of $\mathrm{C}$ and potentially important active soil. Our study also revealed the increased glomalin concentration in mycorrhizal treated soil than untreated soil due to increased biological activity as indicted by increased dehydrogenase activity and biomass carbon. The amount of $\mathrm{C}$ in glomalin represented 4$5 \%$ of total $\mathrm{C}$ which might have contributed to the increased soil C under AM inoculated soil. Radio carbon dating defined glomain has residence time of 6 - 42 years in soil, which is much longer than the residence time reported for hyphae, this could influence soil $\mathrm{C}$ storage indirectly by stable soil aggregates (Rillig et al., 2002). Rillig et al., (2003) report that glomalin concentration was consistently and highly positively correlated with soil C. Our results also suggest that glomalin acts as $\mathrm{C}$ sink in tropical condition and it act as adsorptive site of $\mathrm{Zn}$ thus made it available to plants. 
Table.1 Mean for bacteria, fungi and actinomycetes population in soils at $75(\mathrm{n}=4)$ days after sowing (DAS) under different levels of $\mathrm{P}\left(15\right.$ and $\left.30 \mathrm{mg} \mathrm{kg}^{-1}\right)$ and $\mathrm{Zn}\left(0,1.25\right.$ and $\left.2.5 \mathrm{mg} \mathrm{kg}^{-1}\right)$ with $(\mathrm{M}+)$ or without (M-) mycorrhizal inoculation. Values in parentheses indicate the standard error and the levels of significance for ANOVA $* \mathrm{P} \leq 0.05$; * $\mathrm{P} \leq 0.01$; NS, not significant

\begin{tabular}{|c|c|c|c|c|c|c|}
\hline \multirow{3}{*}{$\begin{array}{l}\text { Treatments } \\
\left(\mathrm{kg} \mathrm{ha}^{-1}\right)\end{array}$} & \multicolumn{6}{|c|}{75 DAS } \\
\hline & \multicolumn{2}{|c|}{ Bacteria } & \multicolumn{2}{|c|}{ Fungi } & \multicolumn{2}{|c|}{ Actinomycetes } \\
\hline & $\mathrm{M}+$ & M- & M+ & M- & $\mathrm{M}+$ & M- \\
\hline P15 Zn 0 & $\begin{array}{c}30.0 \\
(1.528)\end{array}$ & $\begin{array}{c}18.3 \\
(1.453)\end{array}$ & $\begin{array}{c}17.3 \\
(1.202)\end{array}$ & $\begin{array}{c}13.3 \\
(0.882)\end{array}$ & $\begin{array}{c}7.7 \\
(0.662)\end{array}$ & $\begin{array}{c}2.0 \\
(0.577)\end{array}$ \\
\hline Zn1.25 & $\begin{array}{c}32.3 \\
(2.028)\end{array}$ & $\begin{array}{c}24.0 \\
(2.082)\end{array}$ & $\begin{array}{c}19.7 \\
(0.882)\end{array}$ & $\begin{array}{c}14.7 \\
(1.453)\end{array}$ & $\begin{array}{c}6.7 \\
(0.662)\end{array}$ & $\begin{array}{c}3.0 \\
(0.577)\end{array}$ \\
\hline Zn2.5 & $\begin{array}{c}29.3 \\
(2.333)\end{array}$ & $\begin{array}{c}20.7 \\
(3.844)\end{array}$ & $\begin{array}{c}23.0 \\
(1.528)\end{array}$ & $\begin{array}{c}14.3 \\
(2.186)\end{array}$ & $\begin{array}{c}6.7 \\
(0.331)\end{array}$ & $\begin{array}{c}2.3 \\
(0.882)\end{array}$ \\
\hline P30 Zn 0 & $\begin{array}{c}35.7 \\
(3.283)\end{array}$ & $\begin{array}{c}21.7 \\
(1.202)\end{array}$ & $\begin{array}{c}20.3 \\
(1.453)\end{array}$ & $\begin{array}{c}9.7 \\
(1.453)\end{array}$ & $\begin{array}{c}7.0 \\
(1.000)\end{array}$ & $\begin{array}{c}2.7 \\
(0.667)\end{array}$ \\
\hline Zn1.25 & $\begin{array}{c}30.7 \\
(1.764)\end{array}$ & $\begin{array}{c}20.3 \\
(1.453)\end{array}$ & $\begin{array}{c}16.3 \\
(0.882)\end{array}$ & $\begin{array}{c}8.7 \\
(0.882)\end{array}$ & $\begin{array}{c}6.7 \\
(0.882)\end{array}$ & $\begin{array}{c}3.3 \\
(0.667)\end{array}$ \\
\hline Zn2.5 & $\begin{array}{c}30.0 \\
(3.464)\end{array}$ & $\begin{array}{c}22.3 \\
(2.186)\end{array}$ & $\begin{array}{c}20.0 \\
(1.732)\end{array}$ & $\begin{array}{c}10.7 \\
(0.667)\end{array}$ & $\begin{array}{c}7.3 \\
(1.202)\end{array}$ & $\begin{array}{c}2.0 \\
(0.577)\end{array}$ \\
\hline \multicolumn{7}{|c|}{ Anova: M (Mycorrhiza), P (Phosphorus), Zn (Zinc) } \\
\hline $\mathbf{M}$ & \multicolumn{2}{|c|}{$*$} & \multicolumn{2}{|c|}{$* *$} & \multicolumn{2}{|c|}{$* *$} \\
\hline $\mathbf{P}$ & \multicolumn{2}{|c|}{ NS } & \multicolumn{2}{|c|}{$*$} & \multicolumn{2}{|c|}{ NS } \\
\hline Zn & \multicolumn{2}{|c|}{ NS } & \multicolumn{2}{|c|}{$*$} & \multicolumn{2}{|c|}{ NS } \\
\hline $\mathbf{M} \times \mathbf{P}$ & \multicolumn{2}{|c|}{ NS } & \multicolumn{2}{|c|}{$*$} & \multicolumn{2}{|c|}{ NS } \\
\hline $\mathbf{P} \times \mathrm{Zn}$ & \multicolumn{2}{|c|}{ NS } & \multicolumn{2}{|c|}{$*$} & \multicolumn{2}{|c|}{ NS } \\
\hline $\mathbf{M} \times \mathbf{Z n}$ & \multicolumn{2}{|c|}{ NS } & \multicolumn{2}{|c|}{ NS } & \multicolumn{2}{|c|}{ NS } \\
\hline $\mathbf{M} \times \mathbf{P} \times \mathbf{Z n}$ & \multicolumn{2}{|c|}{ NS } & \multicolumn{2}{|c|}{ NS } & \multicolumn{2}{|c|}{ NS } \\
\hline
\end{tabular}


Table.2 Mean for dehydrogenase and acid phosphatase activities in soil at $55(\mathrm{n}=3)$ and $75(\mathrm{n}=4)$ days after sowing (DAS) under different levels of $\mathrm{P}\left(15\right.$ and $\left.30 \mathrm{mg} \mathrm{kg}^{-1}\right)$ and $\mathrm{Zn}\left(0,1.25\right.$ and $\left.2.5 \mathrm{mg} \mathrm{kg}^{-1}\right)$ with (M+) or without (M-) mycorrhizal inoculation. Values in parentheses indicate the standard error and the levels of significance for ANOVA $* \mathrm{P} \leq 0.05 ; * * \mathrm{P} \leq 0.01$; NS, not significant

\begin{tabular}{|c|c|c|c|c|c|c|c|c|c|c|c|c|}
\hline \multirow{3}{*}{$\begin{array}{c}\text { Treatment } \\
\text { s } \\
\left(\mathrm{kg} \mathrm{ha}^{-1}\right)\end{array}$} & \multicolumn{6}{|c|}{ Dehydrogenase ( $\Delta$ in OD at $485 \mathrm{~nm}$ ) } & \multicolumn{6}{|c|}{ Acid Phosphatase ( $\mu$ g ofPNP/g/min) } \\
\hline & \multicolumn{3}{|c|}{ 55DAS } & \multicolumn{3}{|c|}{75 DAS } & \multicolumn{3}{|c|}{ 55DAS } & \multicolumn{3}{|c|}{75 DAS } \\
\hline & M+ & M- & Mean & M+ & M- & Mean & M+ & M- & Mean & M+ & M- & Mean \\
\hline P15 Zn 0 & $\begin{array}{c}0.417 \\
(0.011)\end{array}$ & $\begin{array}{c}0.323 \\
(0.012)\end{array}$ & 0.37 & $\begin{array}{c}0.658 \\
(0.380)\end{array}$ & $\begin{array}{c}0.443 \\
(0.256)\end{array}$ & 0.55 & $\begin{array}{c}1.921 \\
(0.063)\end{array}$ & $\begin{array}{c}1.518 \\
(0.071)\end{array}$ & 1.72 & $\begin{array}{c}3.266 \\
(1.887)\end{array}$ & $\begin{array}{c}2.360 \\
(1.377)\end{array}$ & 2.81 \\
\hline Zn1.25 & $\begin{array}{c}0.441 \\
(0.009)\end{array}$ & $\begin{array}{c}0.341 \\
(0.004)\end{array}$ & 0.39 & $\begin{array}{c}0.674 \\
(0.389)\end{array}$ & $\begin{array}{c}0.544 \\
(0.315)\end{array}$ & 0.61 & $\begin{array}{c}2.291 \\
(0.083)\end{array}$ & $\begin{array}{c}1.496 \\
(0.057)\end{array}$ & 1.89 & $\begin{array}{c}3.392 \\
(1.959)\end{array}$ & $\begin{array}{c}2.447 \\
(1.414)\end{array}$ & 2.92 \\
\hline $\mathrm{Zn2.5}$ & $\begin{array}{c}0.462 \\
(0.008)\end{array}$ & $\begin{array}{c}0.375 \\
(0.004)\end{array}$ & 0.41 & $\begin{array}{c}0.727 \\
(0.420)\end{array}$ & $\begin{array}{c}0.577 \\
(0.334)\end{array}$ & 0.65 & $\begin{array}{c}1.912 \\
(0.054)\end{array}$ & $\begin{array}{c}1.095 \\
(0.078)\end{array}$ & 1.50 & $\begin{array}{c}3.403 \\
(1.965)\end{array}$ & $\begin{array}{c}2.558 \\
(1.478)\end{array}$ & 2.98 \\
\hline Mean & 0.44 & 0.35 & & 0.68 & 0.52 & & 2.04 & 1.37 & & 3.35 & 2.46 & \\
\hline P30 Zn 0 & $\begin{array}{c}0.642 \\
(0.009)\end{array}$ & $\begin{array}{c}0.425 \\
(0.006)\end{array}$ & 0.53 & $\begin{array}{c}0.735 \\
(0.425)\end{array}$ & $\begin{array}{c}0.637 \\
(0.368)\end{array}$ & 0.69 & $\begin{array}{c}2.009 \\
(0.053)\end{array}$ & $\begin{array}{c}1.300 \\
(0.043)\end{array}$ & 1.65 & $\begin{array}{c}3.332 \\
(0.916)\end{array}$ & $\begin{array}{c}2.693 \\
(1.555)\end{array}$ & 3.01 \\
\hline Zn1.25 & $\begin{array}{c}0.712 \\
(0.016)\end{array}$ & $\begin{array}{c}0.445 \\
(0.007)\end{array}$ & 0.59 & $\begin{array}{c}0.752 \\
(0.434)\end{array}$ & $\begin{array}{c}0.653 \\
(0.378)\end{array}$ & 0.70 & $\begin{array}{c}2.872 \\
(0.226)\end{array}$ & $\begin{array}{c}2.326 \\
(0.050)\end{array}$ & 2.59 & $\begin{array}{c}3.419 \\
(0.975)\end{array}$ & $\begin{array}{c}2.743 \\
(1.584)\end{array}$ & 3.08 \\
\hline Zn2.5 & $\begin{array}{c}0.749 \\
(0.010)\end{array}$ & $\begin{array}{c}0.542 \\
(0.009)\end{array}$ & 0.65 & $\begin{array}{c}0.769 \\
(0.444)\end{array}$ & $\begin{array}{c}0.682 \\
(0.395)\end{array}$ & 0.73 & $\begin{array}{c}2.802 \\
(0.086)\end{array}$ & $\begin{array}{c}2.275 \\
(0.226)\end{array}$ & 2.54 & $\begin{array}{c}3.552 \\
(2.052)\end{array}$ & $\begin{array}{c}2.799 \\
(1.616)\end{array}$ & 3.17 \\
\hline Mean & 0.70 & 0.47 & & 0.75 & 0.66 & & 2.56 & 1.97 & & 3.43 & 2.75 & \\
\hline \multicolumn{13}{|c|}{ Anova: M (Mycorrhiza), P (Phosphorus), Zn (Zinc) } \\
\hline M & \multicolumn{3}{|c|}{$* *$} & \multicolumn{3}{|c|}{$* *$} & \multicolumn{3}{|c|}{$* *$} & \multicolumn{3}{|c|}{$* *$} \\
\hline $\mathbf{P}$ & \multicolumn{3}{|c|}{$* *$} & \multicolumn{3}{|c|}{$* *$} & \multicolumn{3}{|c|}{$* *$} & \multicolumn{3}{|c|}{$* *$} \\
\hline Zn & \multicolumn{3}{|c|}{$* *$} & \multicolumn{3}{|c|}{$* *$} & \multicolumn{3}{|c|}{$* *$} & \multicolumn{3}{|c|}{$* *$} \\
\hline $\mathbf{M} \mathbf{x}$ & \multicolumn{3}{|c|}{$* *$} & \multicolumn{3}{|c|}{$* *$} & \multicolumn{3}{|c|}{ NS } & \multicolumn{3}{|c|}{$* *$} \\
\hline $\mathbf{P} \times \mathbf{Z n}$ & \multicolumn{3}{|c|}{$* *$} & \multicolumn{3}{|c|}{$* *$} & \multicolumn{3}{|c|}{$* *$} & \multicolumn{3}{|c|}{ NS } \\
\hline $\mathbf{M} \times \mathbf{Z n}$ & \multicolumn{3}{|c|}{$*$} & \multicolumn{3}{|c|}{$* *$} & \multicolumn{3}{|c|}{ NS } & \multicolumn{3}{|c|}{ NS } \\
\hline M $\times \mathbf{P} \times \mathbf{Z n}$ & \multicolumn{3}{|c|}{ NS } & & $* *$ & & & NS & & & $*$ & \\
\hline
\end{tabular}


Table.3 Mean for biomass carbon and glomalin content in soil at $55(\mathrm{n}=3)$ and $75(\mathrm{n}=4)$ days after sowing (DAS) under different levels of $\mathrm{P}\left(15\right.$ and $\left.30 \mathrm{mg} \mathrm{kg}^{-1}\right)$ and $\mathrm{Zn}\left(0,1.25\right.$ and $\left.2.5 \mathrm{mg} \mathrm{kg}^{-1}\right)$ with $(\mathrm{M}+)$ or without (M-) mycorrhizal inoculation. Values in parentheses indicate the standard error and the levels of significance for ANOVA $* \mathrm{P} \leq 0.05 ; * * \mathrm{P} \leq 0.01$; NS, not significant

\begin{tabular}{|c|c|c|c|c|c|c|c|c|c|c|c|c|}
\hline \multirow{3}{*}{$\begin{array}{c}\text { Treatments } \\
\text { (kg ha-1) }\end{array}$} & \multicolumn{6}{|c|}{ Biomass carbon $\left(\mathrm{mg} \mathrm{kg}^{-1}\right)$} & \multicolumn{6}{|c|}{ Glomalin (mg g $\left.{ }^{-1}\right)$} \\
\hline & \multicolumn{3}{|c|}{55 DAS } & \multicolumn{3}{|c|}{75 DAS } & \multicolumn{3}{|c|}{55 DAS } & \multicolumn{3}{|c|}{75 DAS } \\
\hline & $\mathrm{M}+$ & M- & Mean & $\mathrm{M}+$ & M- & Mean & M+ & M- & Mean & $\mathrm{M}+$ & M- & Mean \\
\hline P15 Zn0 & $\begin{array}{c}36.00 \\
(9.000)\end{array}$ & $\begin{array}{c}27.00 \\
(0.000)\end{array}$ & 31.500 & $\begin{array}{c}54.00 \\
(0.000)\end{array}$ & $\begin{array}{c}47.00 \\
(0.0013)\end{array}$ & $\mathbf{5 0 . 5 0}$ & $\begin{array}{c}0.40 \\
(0.060)\end{array}$ & $\begin{array}{c}0.31 \\
(0.076)\end{array}$ & 0.36 & $\begin{array}{c}0.56 \\
(0.345)\end{array}$ & $\begin{array}{c}0.42 \\
(0.246)\end{array}$ & 0.51 \\
\hline Zn1.25 & $\begin{array}{c}45.00 \\
(9.000)\end{array}$ & $\begin{array}{c}27.00 \\
(0.000)\end{array}$ & 36.000 & $\begin{array}{c}54.00 \\
(0.0011)\end{array}$ & $\begin{array}{c}54.00 \\
(0.0011)\end{array}$ & 54.00 & $\begin{array}{c}0.43 \\
(0.040)\end{array}$ & $\begin{array}{c}0.32 \\
(0.065)\end{array}$ & 0.38 & $\begin{array}{c}0.70 \\
(0.362)\end{array}$ & $\begin{array}{c}0.49 \\
(0.288)\end{array}$ & 0.56 \\
\hline $\mathrm{Zn2.5}$ & $\begin{array}{c}54.00 \\
(15.58)\end{array}$ & $\begin{array}{c}36.00 \\
(9.000)\end{array}$ & 45.000 & $\begin{array}{c}61.00 \\
(0.0007)\end{array}$ & $\begin{array}{c}47.00 \\
(0.0007)\end{array}$ & 54.00 & $\begin{array}{c}0.52 \\
(0.070)\end{array}$ & $\begin{array}{c}0.40 \\
(0.090)\end{array}$ & 0.49 & $\begin{array}{c}0.75 \\
(0.385)\end{array}$ & $\begin{array}{c}0.57 \\
(0.331)\end{array}$ & 0.62 \\
\hline Mean & 45.00 & 30.00 & & 56.33 & 49.33 & & 0.45 & 0.34 & & 0.63 & 0.49 & \\
\hline P30 Zn0 & $\begin{array}{c}45.00 \\
(9.000)\end{array}$ & $\begin{array}{c}27.00 \\
(0.000)\end{array}$ & 36.000 & $\begin{array}{c}68.00 \\
(0.0008)\end{array}$ & $\begin{array}{c}47.00 \\
(0.0007)\end{array}$ & $\mathbf{5 7 . 5 0}$ & $\begin{array}{c}0.61 \\
(0.070)\end{array}$ & $\begin{array}{c}0.43 \\
(0.060)\end{array}$ & 0.52 & $\begin{array}{c}0.81 \\
(0.471)\end{array}$ & $\begin{array}{c}0.61 \\
(0.357)\end{array}$ & 0.71 \\
\hline Zn1.25 & $\begin{array}{c}54.00 \\
(15.58)\end{array}$ & $\begin{array}{c}36.00 \\
(9.000)\end{array}$ & 45.000 & $\begin{array}{c}61.00 \\
(0.0007)\end{array}$ & $\begin{array}{c}54.00 \\
(0.0011)\end{array}$ & $\mathbf{5 7 . 5 0}$ & $\begin{array}{c}0.65 \\
(0.040)\end{array}$ & $\begin{array}{c}0.45 \\
(0.051)\end{array}$ & 0.55 & $\begin{array}{c}0.89 \\
(0.517)\end{array}$ & $\begin{array}{c}0.63 \\
(0.366)\end{array}$ & 0.76 \\
\hline $\mathrm{Zn2.5}$ & $\begin{array}{c}72.00 \\
(9.000)\end{array}$ & $\begin{array}{c}36.00 \\
(9.000)\end{array}$ & 54.000 & $\begin{array}{c}74.00 \\
(0.0007)\end{array}$ & $\begin{array}{c}47.00 \\
(0.0013)\end{array}$ & 60.50 & $\begin{array}{c}0.69 \\
(0.026)\end{array}$ & $\begin{array}{c}0.46 \\
(0.040)\end{array}$ & 0.58 & $\begin{array}{c}0.96 \\
(0.561)\end{array}$ & $\begin{array}{c}0.72 \\
(0.417)\end{array}$ & 0.84 \\
\hline Mean & 57.00 & 33.00 & & 67.67 & 49.33 & & 0.65 & 0.43 & & 0.89 & 0.65 & \\
\hline \multicolumn{13}{|c|}{ ANOVA: M (Mycorrhiza), P (Phosphorus), Zn (Zinc) } \\
\hline M & \multicolumn{3}{|c|}{$*$} & \multicolumn{3}{|c|}{$*$} & \multicolumn{3}{|c|}{$* *$} & \multicolumn{3}{|c|}{$* *$} \\
\hline $\mathbf{P}$ & \multicolumn{3}{|c|}{$* *$} & \multicolumn{3}{|c|}{ NS } & \multicolumn{3}{|c|}{$* *$} & \multicolumn{3}{|c|}{$* *$} \\
\hline Zn & \multicolumn{3}{|c|}{$*$} & \multicolumn{3}{|c|}{ NS } & \multicolumn{3}{|c|}{ NS } & \multicolumn{3}{|c|}{$* *$} \\
\hline$M \times P$ & \multicolumn{3}{|c|}{ NS } & \multicolumn{3}{|c|}{ NS } & \multicolumn{3}{|c|}{ NS } & \multicolumn{3}{|c|}{ NS } \\
\hline$P \times Z n$ & \multicolumn{3}{|c|}{ NS } & \multicolumn{3}{|c|}{ NS } & \multicolumn{3}{|c|}{ NS } & \multicolumn{3}{|c|}{ NS } \\
\hline $\mathbf{M} \times \mathbf{Z n}$ & \multicolumn{3}{|c|}{ NS } & \multicolumn{3}{|c|}{ NS } & \multicolumn{3}{|c|}{ NS } & \multicolumn{3}{|c|}{ NS } \\
\hline M x P x Zn & \multicolumn{3}{|c|}{ NS } & & NS & & & NS & & & NS & \\
\hline
\end{tabular}


Table.4 Mean for organic carbon and available P content in soil at $55(\mathrm{n}=3)$ and $75(\mathrm{n}=4)$ days after sowing (DAS) under different levels of $\mathrm{P}\left(15\right.$ and $\left.30 \mathrm{mg} \mathrm{kg}^{-1}\right)$ and $\mathrm{Zn}\left(0,1.25\right.$ and $\left.2.5 \mathrm{mg} \mathrm{kg}^{-1}\right)$ with $(\mathrm{M}+)$ or without $(\mathrm{M}-)$ mycorrhizal inoculation. Values in parentheses indicate the standard error and the levels of significance for ANOVA $* \mathrm{P} \leq 0.05 ; * * \mathrm{P} \leq 0.01$; NS, not significant

\begin{tabular}{|c|c|c|c|c|c|c|c|c|c|c|c|c|}
\hline \multirow{3}{*}{$\begin{array}{c}\text { Treatments } \\
\left(\mathrm{kg} \mathrm{ha}^{-1}\right)\end{array}$} & \multicolumn{6}{|c|}{ Organic carbon( $(\%)$} & \multicolumn{6}{|c|}{ Soil P $\left(\mathrm{mg} \mathrm{kg}^{-1}\right)$} \\
\hline & \multicolumn{3}{|c|}{55 DAS } & \multicolumn{3}{|c|}{75 DAS } & \multicolumn{3}{|c|}{55 DAS } & \multicolumn{3}{|c|}{75 DAS } \\
\hline & M+ & M- & Mean & M+ & M- & Mean & M+ & M- & Mean & M+ & M- & Mean \\
\hline P15 Zn 0 & $\begin{array}{c}0.23 \\
(0.020)\end{array}$ & $\begin{array}{c}0.21 \\
(0.017)\end{array}$ & 0.22 & $\begin{array}{c}0.30 \\
(0.017)\end{array}$ & $\begin{array}{c}0.23 \\
(0.015)\end{array}$ & 0.26 & $\begin{array}{c}9.91 \\
(0.97)\end{array}$ & $\begin{array}{c}7.30 \\
(1.04)\end{array}$ & 8.66 & $\begin{array}{c}7.10 \\
(0.18)\end{array}$ & $\begin{array}{c}5.63 \\
(0.29)\end{array}$ & 6.40 \\
\hline Zn1.25 & $\begin{array}{c}0.23 \\
(0.010)\end{array}$ & $\begin{array}{c}0.21 \\
(0.000)\end{array}$ & 0.22 & $\begin{array}{c}0.31 \\
(0.008)\end{array}$ & $\begin{array}{c}0.26 \\
(0.009)\end{array}$ & 0.28 & $\begin{array}{l}10.90 \\
(1.11)\end{array}$ & $\begin{array}{c}8.23 \\
(1.09)\end{array}$ & 9.54 & $\begin{array}{c}8.72 \\
(0.16)\end{array}$ & $\begin{array}{c}6.14 \\
(0.17)\end{array}$ & 7.42 \\
\hline Zn2.5 & $\begin{array}{c}0.26 \\
(0.010)\end{array}$ & $\begin{array}{c}0.22 \\
(0.026)\end{array}$ & 0.24 & $\begin{array}{c}0.31 \\
(0.008)\end{array}$ & $\begin{array}{c}0.23 \\
(0.008)\end{array}$ & 0.27 & $\begin{array}{l}12.42 \\
(0.71)\end{array}$ & $\begin{array}{c}9.76 \\
(1.28)\end{array}$ & 11.13 & $\begin{array}{c}9.90 \\
(0.18)\end{array}$ & $\begin{array}{c}7.60 \\
(0.21)\end{array}$ & 8.80 \\
\hline Mean & 0.24 & 0.21 & & 0.31 & 0.24 & & 11.10 & 8.40 & & 8.62 & 6.42 & \\
\hline P30 Zn 0 & $\begin{array}{c}0.27 \\
(0.032)\end{array}$ & $\begin{array}{c}0.25 \\
(0.020)\end{array}$ & 0.26 & $\begin{array}{c}0.31 \\
(0.008)\end{array}$ & $\begin{array}{c}0.26 \\
(0.009)\end{array}$ & 0.28 & $\begin{array}{l}15.42 \\
(1.57)\end{array}$ & $\begin{array}{l}12.02 \\
(1.53)\end{array}$ & 13.70 & $\begin{array}{l}12.10 \\
(0.13)\end{array}$ & $\begin{array}{l}10.00 \\
(0.25)\end{array}$ & 11.33 \\
\hline Zn1.25 & $\begin{array}{c}0.28 \\
(0.013)\end{array}$ & $\begin{array}{c}0.23 \\
(0.026)\end{array}$ & 0.26 & $\begin{array}{c}0.33 \\
(0.021)\end{array}$ & $\begin{array}{c}0.27 \\
(0.024)\end{array}$ & 0.30 & $\begin{array}{l}16.80 \\
(1.36)\end{array}$ & $\begin{array}{l}13.00 \\
(1.11)\end{array}$ & 14.92 & $\begin{array}{l}13.57 \\
(0.22)\end{array}$ & $\begin{array}{l}10.31 \\
(0.41)\end{array}$ & 11.90 \\
\hline $\mathrm{Zn} 2.5$ & $\begin{array}{c}0.28 \\
(0.026)\end{array}$ & $\begin{array}{c}0.25 \\
(0.019)\end{array}$ & 0.27 & $\begin{array}{c}0.35 \\
(0.016)\end{array}$ & $\begin{array}{c}0.28 \\
(0.031)\end{array}$ & 0.31 & $\begin{array}{l}17.93 \\
(1.18)\end{array}$ & $\begin{array}{l}14.82 \\
(1.86)\end{array}$ & 16.40 & $\begin{array}{l}15.55 \\
(0.23)\end{array}$ & $\begin{array}{c}9.72 \\
(0.33)\end{array}$ & 12.74 \\
\hline Mean & 0.33 & 0.27 & & 0.33 & 0.27 & & 16.74 & 13.34 & & 13.70 & 10.20 & \\
\hline \multicolumn{13}{|c|}{ ANOVA: M (Mycorrhiza), P (Phosphorus), Zn (Zinc) } \\
\hline $\mathbf{M}$ & \multicolumn{3}{|c|}{$* *$} & \multicolumn{3}{|c|}{$* *$} & \multicolumn{3}{|c|}{$* *$} & \multicolumn{3}{|c|}{$* *$} \\
\hline $\mathbf{P}$ & \multicolumn{3}{|c|}{$* *$} & \multicolumn{3}{|c|}{$* *$} & \multicolumn{3}{|c|}{ ** } & \multicolumn{3}{|c|}{$* *$} \\
\hline $\mathbf{Z n}$ & \multicolumn{3}{|c|}{ NS } & \multicolumn{3}{|c|}{ NS } & \multicolumn{3}{|c|}{$* *$} & \multicolumn{3}{|c|}{$* *$} \\
\hline $\mathbf{M} \times \mathbf{P}$ & \multicolumn{3}{|c|}{ NS } & \multicolumn{3}{|c|}{ NS } & \multicolumn{3}{|c|}{ NS } & \multicolumn{3}{|c|}{$* *$} \\
\hline $\mathbf{P} \times \mathbf{Z n}$ & \multicolumn{3}{|c|}{ NS } & \multicolumn{3}{|c|}{ NS } & \multicolumn{3}{|c|}{ NS } & \multicolumn{3}{|c|}{$* *$} \\
\hline Mx Zn & \multicolumn{3}{|c|}{ NS } & \multicolumn{3}{|c|}{ NS } & \multicolumn{3}{|c|}{ NS } & \multicolumn{3}{|c|}{$* *$} \\
\hline$M \times P \times Z n$ & \multicolumn{3}{|c|}{ NS } & & NS & & & NS & & & $* *$ & \\
\hline
\end{tabular}


Table.5 Mean for DTPA-Fe and Mn content in soil at $55(\mathrm{n}=3)$ and $75(\mathrm{n}=4)$ days after sowing (DAS) under different levels of P $\left(15\right.$ and $\left.30 \mathrm{mg} \mathrm{kg}^{-1}\right)$ and $\mathrm{Zn}\left(0,1.25\right.$ and $\left.2.5 \mathrm{mg} \mathrm{kg}^{-1}\right)$ with $(\mathrm{M}+)$ or without $(\mathrm{M}-)$ mycorrhizal inoculation. Values in parentheses indicate the standard error and the levels of significance for ANOVA $* \mathrm{P} \leq 0.05 ; * * \mathrm{P} \leq 0.01$; NS, not significant

\begin{tabular}{|c|c|c|c|c|c|c|c|c|c|c|c|c|}
\hline \multirow{3}{*}{$\begin{array}{l}\text { Treatments } \\
\left(\mathrm{kg} \mathrm{ha}^{-1}\right)\end{array}$} & \multicolumn{6}{|c|}{ DTPA-Fe } & \multicolumn{6}{|c|}{ DTPA-Mn } \\
\hline & \multicolumn{3}{|c|}{ 55DAS } & \multicolumn{3}{|c|}{75 DAS } & \multicolumn{3}{|c|}{ 55DAS } & \multicolumn{3}{|c|}{75 DAS } \\
\hline & $\mathrm{M}+$ & M- & Mean & M+ & M- & Mean & M+ & M- & Mean & M+ & M- & Mean \\
\hline P15 Zn 0 & $\begin{array}{c}8.11 \\
(0.116)\end{array}$ & $\begin{array}{c}6.20 \\
(0.067)\end{array}$ & 7.15 & $\begin{array}{c}8.32 \\
(0.331)\end{array}$ & $\begin{array}{c}7.04 \\
(0.399)\end{array}$ & 7.68 & $\begin{array}{c}11.12 \\
(0.320)\end{array}$ & $\begin{array}{c}8.16 \\
(0.754)\end{array}$ & 9.64 & $\begin{array}{c}11.56 \\
(0.295)\end{array}$ & $\begin{array}{c}7.14 \\
(0.703)\end{array}$ & 9.35 \\
\hline Zn1.25 & $\begin{array}{c}8.70 \\
(0.097)\end{array}$ & $\begin{array}{c}6.63 \\
(0.036)\end{array}$ & 7.67 & $\begin{array}{c}8.78 \\
(0.241)\end{array}$ & $\begin{array}{c}7.30 \\
(0.484)\end{array}$ & 8.04 & $\begin{array}{c}11.46 \\
(0.659)\end{array}$ & $\begin{array}{c}8.76 \\
(0.583)\end{array}$ & 10.11 & $\begin{array}{c}12.72 \\
(0.271)\end{array}$ & $\begin{array}{c}7.87 \\
(0.650)\end{array}$ & 10.30 \\
\hline Zn2.5 & $\begin{array}{c}9.22 \\
(0.125)\end{array}$ & $\begin{array}{c}7.45 \\
(0.137)\end{array}$ & 8.34 & $\begin{array}{c}9.34 \\
(0.265)\end{array}$ & $\begin{array}{c}7.34 \\
(0.573)\end{array}$ & 8.34 & $\begin{array}{c}12.14 \\
(0.249)\end{array}$ & $\begin{array}{c}9.14 \\
(1.007)\end{array}$ & 10.64 & $\begin{array}{c}13.14 \\
(0.427)\end{array}$ & $\begin{array}{c}8.59 \\
(0.460)\end{array}$ & 10.87 \\
\hline Mean & 8.68 & 6.76 & & 8.81 & 7.23 & & 11.57 & 8.69 & & 12.47 & 7.87 & \\
\hline P30 Zn 0 & $\begin{array}{c}7.54 \\
(0.050)\end{array}$ & $\begin{array}{c}5.63 \\
(0.127)\end{array}$ & 6.59 & $\begin{array}{c}7.81 \\
(0.320)\end{array}$ & $\begin{array}{c}6.72 \\
(0.561)\end{array}$ & 7.27 & $\begin{array}{c}12.79 \\
(1.003)\end{array}$ & $\begin{array}{c}9.67 \\
(0.777)\end{array}$ & 11.23 & $\begin{array}{c}13.57 \\
(0.286)\end{array}$ & $\begin{array}{c}8.21 \\
(0.651)\end{array}$ & 10.89 \\
\hline Zn1.25 & $\begin{array}{c}8.01 \\
(0.113)\end{array}$ & $\begin{array}{c}6.06 \\
(0.076)\end{array}$ & 7.03 & $\begin{array}{c}8.14 \\
(0.260)\end{array}$ & $\begin{array}{c}6.81 \\
(0.427)\end{array}$ & 7.48 & $\begin{array}{c}13.12 \\
(1.147)\end{array}$ & $\begin{array}{c}10.05 \\
(0.981)\end{array}$ & 11.59 & $\begin{array}{c}13.88 \\
(0.307)\end{array}$ & $\begin{array}{c}7.56 \\
(0.612)\end{array}$ & 10.72 \\
\hline Zn2.5 & $\begin{array}{c}8.49 \\
(0.066)\end{array}$ & $\begin{array}{c}6.33 \\
(0.073)\end{array}$ & 7.41 & $\begin{array}{c}8.52 \\
(0.254)\end{array}$ & $\begin{array}{c}6.95 \\
(0.497)\end{array}$ & 7.74 & $\begin{array}{c}13.45 \\
(0.621)\end{array}$ & $\begin{array}{c}10.22 \\
(0.662)\end{array}$ & 11.84 & $\begin{array}{c}14.02 \\
(0.347)\end{array}$ & $\begin{array}{c}7.80 \\
(0.575)\end{array}$ & 10.91 \\
\hline Mean & 8.01 & 6.01 & & 8.16 & 6.83 & & 13.12 & 9.98 & & 13.82 & 7.86 & \\
\hline \multicolumn{13}{|c|}{ Anova: M (Mycorrhiza), P (Phosphorus), Zn (Zinc) } \\
\hline $\mathbf{M}$ & \multicolumn{3}{|c|}{$* *$} & \multicolumn{3}{|c|}{$* *$} & \multicolumn{3}{|c|}{$* *$} & \multicolumn{3}{|c|}{$* *$} \\
\hline $\mathbf{P}$ & \multicolumn{3}{|c|}{$* *$} & \multicolumn{3}{|c|}{$*$} & \multicolumn{3}{|c|}{$* *$} & \multicolumn{3}{|c|}{$*$} \\
\hline $\mathbf{Z n}$ & \multicolumn{3}{|c|}{$* *$} & \multicolumn{3}{|c|}{ NS } & \multicolumn{3}{|c|}{ NS } & \multicolumn{3}{|c|}{ NS } \\
\hline $\mathbf{M} \times \mathbf{P}$ & \multicolumn{3}{|c|}{ NS } & \multicolumn{3}{|c|}{ NS } & \multicolumn{3}{|c|}{ NS } & \multicolumn{3}{|c|}{$*$} \\
\hline $\mathbf{P} \times \mathbf{Z n}$ & \multicolumn{3}{|c|}{$*$} & \multicolumn{3}{|c|}{ NS } & \multicolumn{3}{|c|}{ NS } & \multicolumn{3}{|c|}{ NS } \\
\hline M x Zn & \multicolumn{3}{|c|}{ NS } & \multicolumn{3}{|c|}{ NS } & \multicolumn{3}{|c|}{ NS } & \multicolumn{3}{|c|}{ NS } \\
\hline $\mathbf{M} \times \mathbf{P} \times \mathbf{Z n}$ & \multicolumn{3}{|c|}{ NS } & & NS & & & NS & & & NS & \\
\hline
\end{tabular}


Table.6 Mean for DTPA $\mathrm{Zn}$ and $\mathrm{Cu}$ in soils at $55(\mathrm{n}=3)$ and $75(\mathrm{n}=4)$ days after sowing (DAS) under different levels of P (15 and $\left.30 \mathrm{mg} \mathrm{kg}^{-1}\right)$ and $\mathrm{Zn}\left(0,1.25\right.$ and $\left.2.5 \mathrm{mg} \mathrm{kg}^{-1}\right)$ with $(\mathrm{M}+)$ or without (M-) mycorrhizal inoculation. Values in parentheses indicate the standard error and the levels of significance for ANOVA $* \mathrm{P} \leq 0.05 ; * * \mathrm{P} \leq 0.01$; NS, not significant

\begin{tabular}{|c|c|c|c|c|c|c|c|c|c|c|c|c|}
\hline \multirow{3}{*}{$\begin{array}{l}\text { Treatments } \\
\quad\left(\mathrm{kg} \mathrm{ha}^{-1}\right)\end{array}$} & \multicolumn{6}{|c|}{ DTPA-Zn } & \multicolumn{6}{|c|}{ DTPA-Cu } \\
\hline & \multicolumn{3}{|c|}{ 55DAS } & \multicolumn{3}{|c|}{75 DAS } & \multicolumn{3}{|c|}{ 55DAS } & \multicolumn{3}{|c|}{75 DAS } \\
\hline & M+ & M- & Mean & M+ & M- & Mean & M+ & M- & Mean & M+ & M- & Mean \\
\hline P15 Zn 0 & $\begin{array}{c}3.02 \\
(0.21)\end{array}$ & $\begin{array}{c}2.50 \\
(0.41)\end{array}$ & 2.80 & $\begin{array}{c}3.74 \\
(0.25)\end{array}$ & $\begin{array}{c}3.70 \\
(0.15)\end{array}$ & 3.72 & $\begin{array}{c}0.513 \\
(0.137)\end{array}$ & $\begin{array}{c}0.313 \\
(0.022)\end{array}$ & 0.413 & $\begin{array}{c}0.314 \\
(0.029)\end{array}$ & $\begin{array}{c}0.221 \\
(0.017)\end{array}$ & 0.268 \\
\hline Zn1.25 & $\begin{array}{c}6.40 \\
(0.45)\end{array}$ & $\begin{array}{c}3.82 \\
(0.36)\end{array}$ & 5.10 & $\begin{array}{c}6.76 \\
(0.99)\end{array}$ & $\begin{array}{c}4.34 \\
(0.12)\end{array}$ & 5.63 & $\begin{array}{c}0.535 \\
(0.028)\end{array}$ & $\begin{array}{c}0.327 \\
(0.020)\end{array}$ & 0.431 & $\begin{array}{c}0.511 \\
(0.014)\end{array}$ & $\begin{array}{c}0.238 \\
(0.059)\end{array}$ & 0.375 \\
\hline Zn2.5 & $\begin{array}{c}8.17 \\
(0.35)\end{array}$ & $\begin{array}{c}4.18 \\
(0.56)\end{array}$ & 6.17 & $\begin{array}{c}8.90 \\
(0.11)\end{array}$ & $\begin{array}{c}7.80 \\
(0.08)\end{array}$ & 8.30 & $\begin{array}{c}0.649 \\
(0.018)\end{array}$ & $\begin{array}{c}0.342 \\
(0.020)\end{array}$ & 0.496 & $\begin{array}{c}0.545 \\
(0.018)\end{array}$ & $\begin{array}{c}0.242 \\
(0.099)\end{array}$ & 0.394 \\
\hline Mean & 5.80 & 3.50 & & 6.54 & 5.28 & & 0.566 & 0.327 & & 0.457 & 0.234 & \\
\hline P30 Zn 0 & $\begin{array}{c}3.82 \\
(0.35)\end{array}$ & $\begin{array}{c}4.25 \\
(0.62)\end{array}$ & 4.13 & $\begin{array}{c}4.10 \\
(0.09)\end{array}$ & $\begin{array}{c}2.40 \\
(0.11)\end{array}$ & 3.20 & $\begin{array}{c}0.614 \\
(0.020)\end{array}$ & $\begin{array}{c}0.344 \\
(0.017)\end{array}$ & 0.479 & $\begin{array}{c}0.394 \\
(0.159)\end{array}$ & $\begin{array}{c}0.278 \\
(0.018)\end{array}$ & 0.336 \\
\hline Zn1.25 & $\begin{array}{c}9.70 \\
(0.53)\end{array}$ & $\begin{array}{c}6.60 \\
(0.59)\end{array}$ & 8.24 & $\begin{array}{c}9.92 \\
(0.15)\end{array}$ & $\begin{array}{c}3.52 \\
(0.10)\end{array}$ & 6.71 & $\begin{array}{c}0.654 \\
(0.022)\end{array}$ & $\begin{array}{c}0.372 \\
(0.020)\end{array}$ & 0.513 & $\begin{array}{c}0.524 \\
(0.184)\end{array}$ & $\begin{array}{c}0.303 \\
(0.040)\end{array}$ & 0.414 \\
\hline Zn2.5 & $\begin{array}{l}11.42 \\
(0.49)\end{array}$ & $\begin{array}{c}7.92 \\
(0.56)\end{array}$ & 9.60 & $\begin{array}{l}10.76 \\
(0.39)\end{array}$ & $\begin{array}{c}3.91 \\
(0.08)\end{array}$ & 7.46 & $\begin{array}{c}0.675 \\
(0.026)\end{array}$ & $\begin{array}{c}0.375 \\
(0.016)\end{array}$ & 0.525 & $\begin{array}{c}0.574 \\
(0.200)\end{array}$ & $\begin{array}{c}0.325 \\
(0.068)\end{array}$ & 0.450 \\
\hline Mean & 8.36 & 6.38 & & 8.29 & 3.20 & & 0.648 & 0.364 & & 0.497 & 0.302 & \\
\hline \multicolumn{13}{|c|}{ Anova: M (Mycorrhiza), P (Phosphorus), Zn (Zinc) } \\
\hline $\mathbf{M}$ & \multicolumn{3}{|c|}{$* *$} & \multicolumn{3}{|c|}{$* *$} & \multicolumn{3}{|c|}{$* *$} & \multicolumn{3}{|c|}{$* *$} \\
\hline $\mathbf{P}$ & \multicolumn{3}{|c|}{$* *$} & \multicolumn{3}{|c|}{ NS } & \multicolumn{3}{|c|}{ * } & \multicolumn{3}{|c|}{$* *$} \\
\hline Zn & \multicolumn{3}{|c|}{$* *$} & \multicolumn{3}{|c|}{$* *$} & \multicolumn{3}{|c|}{ NS } & \multicolumn{3}{|c|}{$* *$} \\
\hline $\mathbf{M} \times \mathbf{P}$ & \multicolumn{3}{|c|}{ NS } & \multicolumn{3}{|c|}{$* *$} & \multicolumn{3}{|c|}{ NS } & \multicolumn{3}{|c|}{ NS } \\
\hline $\mathbf{P} \times \mathbf{Z n}$ & \multicolumn{3}{|c|}{$* *$} & \multicolumn{3}{|c|}{$* *$} & \multicolumn{3}{|c|}{ NS } & \multicolumn{3}{|c|}{ NS } \\
\hline M x Zn & \multicolumn{3}{|c|}{$* *$} & \multicolumn{3}{|c|}{$* *$} & \multicolumn{3}{|c|}{ NS } & \multicolumn{3}{|c|}{ NS } \\
\hline $\mathbf{M} \times \mathbf{P} \times \mathbf{Z n}$ & \multicolumn{3}{|c|}{ NS } & & $* *$ & & & NS & & & NS & \\
\hline
\end{tabular}


Soil organic carbon pools an important component of terrestrial ecosystems. In the present study AM fungi inoculation improved soil organic carbon status through the growth and turnover of extraradical hyphae besides exudates from hyphae as shown by Marschner et al., (1997). Percentage of colonized root was significantly correlated to labile C fraction in the rhizosphere soil. Mechanisms influencing soil organic carbon storage depend mainly on net primary production and the distribution of photosynthates between above and below ground structure. Graham (2000) reported that AM could drain 4-20\% of carbon from host plant which indirectly influence $\mathrm{C}$ storage in soils. Which in turn influenced the microbial activity in soil. Rillig et al., (2003) reported that organic carbon is positively correlated with glomalin. In the present study also the increased glomalin concentration, biomass carbon in mycorrhizae treated soil might have contributed the presence of high organic carbon in the soil as indicated by Rillig et al., 2002. As mycorrhizal symbiosis utilizes at least $10 \%$ of the host plant photosynthetic C (Fitter, 1988) and the transferred $\mathrm{C}$ enriches microbial activities in the rhizosphere, which may have contributed for the enhancement of active $C$ pool in the soil.

The primary effect of AM symbiosis is to increase the supply of mineral nutrient to the plant particularly those whose ionic forms have a poor mobility rate such as $\mathrm{P}, \mathrm{Zn}$ (Barea, 1991) which resulted in enhanced growth. We found that positive interaction between $\mathrm{P}$ and $\mathrm{Zn}$ in mycorrhizae treated soil resulted in enhanced growth especially root and nutrient uptake. This was supported by Caragnaro et al., (2006). AM can deliver up to $80 \%$ of plant $\mathrm{P}$ and $25 \%$ of plant $\mathrm{Zn}$ (Marschner and Dell 1994). In general, only $P$ in the soil solution and labile pool can be readily taken up by roots and AM fungal hyphae. Efficient nutrient acquisition by AM fungi is generally attributed to the external hyphal growth beyond the nutrient depletion zone surrounding the root and also due to an increase in the no. of uptake sites per unit area of roots (Kim et al., 1988) so that external hyphae are able to explore a large volume of soil. AM increased $\mathrm{P}$ uptake by dissolving complex soil phosphate due to release of organic substance by the roots (Bolan, 1991) especially organic acids viz., citric acid, lactic acid, formic acid and malic acid. Organic acid can carry varying negative charges, thereby allowing the complextation of metal cations in solution and the displacement of anions from the soil matrix. Organic anions function as a organic ligands, which can increase $\mathrm{P}$ in solution by replacing $\mathrm{P}$ sorbed at metal hydroxide surfaces through ligand-exchange reactions, dissolving metal oxide surfaces that sorb $\mathrm{P}$ and complexing metals in solution and thus preventing precipitation of metal phosphates. Further AM infection increased $\mathrm{P}$ availability more from organic $\mathrm{P}$ compared to inorganic P. In our study mycorrhizal inoculation modified the soil biochemistry by increasing organic carbon, biomass carbon and soil enzyme activities which had a positive role on $\mathrm{Zn}$ release from soil. The enhance growth of mycorrhizal hyphae had many adsorptive site for $\mathrm{Zn}$ and also organic substance produced by AM fungi acts as chelating agent and complexed with metallic micronutrient such as $\mathrm{Zn}$ and made it available. Rupa et al., (2003) concluded that $\mathrm{p}$ addition up to $40 \mathrm{mg} \mathrm{kg}^{-1}$ in soil increased plant available zinc in soil whereas at higher $\mathrm{P}$ levels, inhibits zinc translocation. In our study we used $\mathrm{P}$ only up to $30 \mathrm{mg} \mathrm{kg}^{-1}$, hence it might have shown synergistic interaction between $\mathrm{P}$ and zinc.

In both stages AM inoculation increased DTPA- $\mathrm{Fe}, \mathrm{Mn}, \mathrm{Cu}$ in soil above the critical level over uninoculated control regardless of $\mathrm{P}$ and $\mathrm{Zn}$ level. This might be due to enhanced growth of external hyphae which 
acts as extension to plant roots (Turk et al., 2006). At low P levels in soils of soyabean mycorrhiza substantially increases the availability of $\mathrm{Cu}$ and $\mathrm{Zn}$ content (Lambert and Weidebsaul, 1991).

To conclude, Arbuscular mycorrhizal inoculation could improve soil biochemical, enzymatic and organic carbon status, which altogether improved $\mathrm{Zn}$ availability due to synergistic interaction between $\mathrm{Zn}$ and $\mathrm{P}$. Over all this study reveals that AM fungal inoculation is one of the major biochemical component in the soil needed to be considered to nutrient especially micronutrient deficiency.

Abbreviations: $\quad$ AMF- arbuscular mycorrhizal fungus, BMC- biomass carbon, P-Phosphorous, Zn-Zinc, Mn-Manganese, FeIron.

\section{References}

Alguacil, M.M., Caravaca F.and Roldán, A. 2005. Changes in rhizosphere microbial activity mediated by native or allochthonous AM fungi in the reafforestration of a Mediaterranean degraded environment. Soil Biol. Biochem., 41: 59-68.

Allen, E. K. 1953. Experiments in soil micro biology. Burgess. Publ. C., Minnepolis, Minn., P. 107.

Allen, M.F. (1991). The ecology of mycorrhizae. Cambridge University Press, Cambridge.

Ames, R.N., Reid, C.P.P. and Singam, E.R. 1984. Rhizosphere bacterial population responses to root colonization by a vesicular arbuscular mycorrhizl fungus. New Phytol., 87: 687-694.

Barea, J.M., 1991. Vesicular arbuscular mycorrhiza as modifiers of soil fertility. In; B.A. Stewart (editor). Adv. In soil science. Springer- Verlag, New york. pp. 1-40.

Bolan, N.S. 1991. A critical review on the role of mycorrhizal fungi in the uptake of phosphorus by plants. Plant and Soil. 134, 189-207.

Caravaca, F., Figueroa, D. and Roldan, A. 2003. Alteration in rhizosphere soil properties of afforested Rhamnus lyciodes seedlings in short term response to mycorrhizal inoculatiob with Glomus intraradices and organic amendment. Env. Manage., 31(3): 412420.

Cavagnaro, T.R., Jackson, C.E., Six, J., Ferris, H., Goyal, S., Asami, D. and Scow, K.M. 2006. Arbuscular mycorrhizas, microbial communities, nutrient availability and soil aggregates in organic tomato production. Plant and Soil. 282 (1-2): 209-225.

Fitter, A.H. 1988. Water relations of red clover Trifolium pretense L. as affected by VA mycorrhizal infection and phosphorus supply before and during drought. J. Expt. Bot. 39: 595-603.

Garcia, C., Roldan, A., and Costa, F. 1997. Potential use of dehydrogenase activity as an index of microbial activity in degraded soils. Communications in Soil Science and Plant Nutrition. 12: 123134.

Gerdemann, J.W. and Nicolson, P.H. 1963. Spores of mycorrhizal Endogone species extracted from soil by wet sieving and decanting. Trans. Brit. Mycol. Soc., 46: 235-244.

Graham, J.H. 2000. Assessing the cost of arbuscular mycorrhizal symbiosis in agroecosystems. In: current advances in mycorrizal Research, pp.127-140. The Americal Phyto pathological society, St. paul, MN.

Hamel, C., Neeser, C., Bannates-Cartin, U., Smith, D.L., 1991. Endomycorrhizal fungal species mediate $15 \mathrm{~N}$ transfer from soybean to maize in non fumigated 
soil. Plant and Soil 138: 41-47.

Hayman, D.S., 1983. The physiology of vesicular-arbuscular mycorrhizal symbiosis. Can. J. Bot. 61: 944-962.

Helal, H.M. and Sauerbeck, D.R. 1991. Soil and root phosphates activity and the utilization of inosital phosphatses as dependent on phosphorus supply. In: Plant roots and their environment. pp. 93-97. Elsevier, Amsterdam.

Jenkinson, D.S. and Powlson, D.S. 1976. Effect of biocidal treatment on metabolism in soil-V.A. method of measuring soil biomass. Soil Biol. Biochem., 8: 209-213.

Joner, E. J., Van Aarle, I.M, Vosatka, M. 2000. Phosphatse activity of extra radical arbuscular mycorrhizal hyphae: a review. Plant and Soil. 226: 199-210.

Kabir, Z., Halloran, I.P.O., Fyles, J.W and Hamel, C. 1998. Dynamics of the mycorrhizal symbiosis of corn (Zea mays L.): effects of host physiology, tillage practice and fertilization on spatial distribution of extra-radical mycorrhizal hyphae in the field. Agriculture, Ecosystems and Environment, 68: 151-163.

Kandeler, E., Marshner, P., Tscherko, D., Gahoonia, T.S. and Nielson, N.K. 2002. Microbial community composition and functional diversity in the rhizosphere of maize. Plant and Soil. 238: 301-312.

Kelly, J.J and Tate, R. L. 1998. Effect of heavy metal contamination and remediation in soil microbizal communities in the vicinity of a zinc smelter. Journal of environmental quality. 27" 609-617.

Kelly, J.J., Haggblom, M., and Tate, R.L., 1999. Changes in soil microbial communities over time resulting from one time application of zinc: a laboratory microcosm study. Soil Biol. Biochem. 31:1455-1465.

Kim, K.Y., Jordan, D., McDonald, G.A.,
1998. Effect of phosphate solubilizing bacteria and vesicular-arbuscular mycorrhizae on tomato growth and soil microbial activity. Biol. Fertil. Soil. 26: 79-87.

Lambert, D. H. and Weidensaul, T.C. 1991. Element uptake by mycorrizal soyabean from sewage sludge treated soil. Soil Sci. Am. J., 55: 393-398.

Lovelock, C.E., Wright, S.F., Clark, D.A. and Ruess, R.W. 2004. Soil stocks of glomalin produced by arbuscular mycorrhizal fungi across a tropical rain forest landscape. J. Ecol., 92: 278287.

Marschner, P., Crowley, D.E., Higashi, M., 1997. Root exudation and physiological status of a root colonizing fluorescent pseudomonad in mycorrhizal and nonmycorrhizal pepper (Capsicum annuum). Plant and Soil. 189: 11-20.

Olsson, P.A, Thingstrup, I., Jakobsen, I.and. Baath, E. 1999. Estimation of the biomass of arbuscular mycorrhizal fungi in a linseed field. Soil Biol. Biochem., 31: 1879-1887.

Rillig, M.C., Ramsey, P.W., Morris,S. and Paul, E.A. 2003. Glomalin, an arbuscular-mycorrhizal fungal soil protein, responds to land-use change. Plant and Soil. 253(2): 293-

299

Rillig, M.C., Wright, S.F. and Eviner, V.T. 2002. The role of arbuscular mycorrhizal fungi and glomailn in soil aggregation: comparing effects of five plant species. Plant and Soil. 238: 325333.

Rillig, M.C., Wright, S.F., Kimball, B.A. and Leavitt, S.W. 2001. Elevated carbon dioxide and irrigation effects on water stable aggregates in a sorghum field: a possible role for arbuscular mycorrhizal fungi. Global Change Biology 7: 333337.

Rillig, M.C., Wright, S.F., Nichols, K.A., 
Schmidt, W.F. and Torn, M.S. 2001. Large contribution of arbuscular mycorrhizal fungi to soil carbon pools in tropical forest soils. Plant and Soil. 233: $167-177$.

Rupa T.R. Srinivasa Rao, C.H., Subbarao, A.and Singh, M.. 2003. Effect of farmyard manure and phophorus on zinc transformation and phyto availability in two Alfisols of India. Bioresour Technol., 87(3): 279-288.

Singh, B., Senthil Kumar, A., Natesan, B., Singh, K. and Usha, K., 2005. Improving zinc use efficiency of cereals under zinc deficiency. Curr. Sci. 88: 3644.

Subramanian, K.S., Bharathi, C.and Jegan, R.A. 2008. Response of maize to mycorrhizal colonization at varying levels of zinc and phosphorus. Biol. Fertil. Soils. 45: 133-144.

Tabatabai, M.A., 1982. Soil enzymes. In: Page, A.L., Miller, R.H., Keeney, D.R., (Eds.) Method of soil analysis, Part 2. Chemical and microbiologicak properties. American Society of Agronomy, Madison, pp. 903-948.

Tarafdar, J.C. 2008. Mobilization of native phosphorus for plant nutrition. J. Indian Soc. Soil Sci., 56(4): 388-394.

Tarafdar, J.C. and Classen N. 1988. Organic phosphorus compounds as a phosphorus source for higher plants through the activity of phosphatases produced by plant roots and microorganisms. Biol. Fertil. Soils. 5: 308-312.

Tarafdar, J.C., Marschner, H., 1994.
Phosphatase activity in the rhizosphere of VA-mycorrhizal wheat supplied with inorganic and organic phosphorus. Soil Biol. Biochem. 26: 387-395.

Tate, R.L. and Terry, R.E., 1980. Variation in microbial activity in histosols and its relationship to soil moisture. Appl. Environ. Microb., 40: 313-317.

Toro, M. Azcon, R.and Barea, J.M.1997. Improvement of arbuscular mycorrihizal evelopment by inoculation with phosphate solubilizing rhizo bacteria to improve rock phosphate bioavaulability 932p) and nutrient cycling. Appl Environ microbial. 63: 4408-4412.

Turk, M.A., Assaf, T.A., Hameed, K.M. and Al-Tawaha, A.M. 2006. Significance of mycorrhizae. World journal of agricultural sciences. 2(1): 16-20.

Walkley, A., Black, C.A., 1934. An estimation of the wet acid method for determining soil organic matter and a proposed modification of the chromic acid titration method. Soil Sci. 37, 29.

Wamberg, C., Christensen, S., Jakobsen, I., Muller, A.K. Sorensen, S.J., 2003. The mycorrhizal fungus (Glomus intraradices) affects microbial activity in the rhizosphere of pea plants (Pisum sativum). Soil Biol. Biochem. 35, 13491357.

Wright, S.F. and Upadhyaya, A. 1998. A survey of soils for aggregate stability and glomalin, a glycoprotein produced by hyphae of arbuscular mycorrhizal fungi. Plant AND Soil. 198: 97-107.

\section{How to cite this article:}

Chandrasekaran Bharathi, Natarajan Balakrishnan and Kizhaeral S. Subramanian. 2019. Biochemical Changes of Mycorrhiza Inoculated and Uninoculated Soils under Differential Zn and P Fertilization. Int.J.Curr.Microbiol.App.Sci. 8(01): 874-890.

doi: https://doi.org/10.20546/ijcmas.2019.801.095 